ISSN: 2302-8556

E-Jurnal Akuntansi Universitas Udayana

Vol.26.2.Februari (2019): 966-996

DOI: https://doi.org/10.24843/EJA.2019.v26.i02.p05

\title{
Pengaruh Partisipasi Penganggaran, Informasi Asimetri, Komitmen Organisasi, dan Ketidakpastian Lingkunganpada Senjangan Anggaran
}

\author{
Ida Bagus Surya Cahyadi Luhur ${ }^{1}$ \\ Ni Luh Supadmi ${ }^{2}$
}

\author{
${ }^{1,2}$ Fakultas Ekonomi dan Bisnis Universitas Udayana (Unud), Bali, Indonesia \\ e-mail: suryaluhur@gmail.
}

\begin{abstract}
ABSTRAK
Anggaran merupakan bagian penting dalam suatu organisasi baik sektor publik maupun perusahaan. Organisasi sektor publik harus selalu memperhatikan faktorfaktor yang dapat mempengaruhi senjangan anggaran, seperti partisipasi penganggaran, informasi asimetri, komitmen organisasi, dan ketidakpastian lingkungan. Tujuan penelitian ini adalah untuk mendapatkan bukti empiris pengaruh partisipasi penganggaran, informasi asimetri, komitmen organisasi, dan ketidakpastian lingkungan pada senjangan anggaran. Populasi penelitian ini adalah Organisasi Perangkat Daerah (OPD) PemerintahKota Denpasar yang berjumlah sebanyak 33 OPD, jumlahpenelitian sampel sebanyak 99 orang pegawai OPD. Teknik analisis data yang digunakan adalah analisis regresi linier berganda.Hasil penelitian menunjukkan bahwa partisipasi penganggaran, informasi asimetri, komitmen organisasi, dan ketidakpastian lingkungan berpengaruh positif pada senjangan anggaran pada Organisasi Perangkat Daerah Pemerintah Kota Denpasar.

Kata kunci : Partisipasi penganggaran, informasi asimetri, komitmen organisasi, ketidakpastian lingkungan, senjangan anggaran
\end{abstract}

\begin{abstract}
Budget is an important part in the activities of both the public and corporate sectors. Sector sector sector sector sector sector Organization Organization Organization Organization Organization Organization Organization Organization Organization Organization Organization Organization Organization can be factor factor factor factor factor factor factor objective The purpose of this research is to find information about budgeting, information asymmetry, commitment organization, and environmental uncertainty on budgetary slack. The population of this research is Regional Device Organization (OPD) in the scope of Denpasar City Government which amounts to 33 OPD, the number of samples obtained by respondents is 99 OPD employees. Data analysis techniques are multiple regression analysis. The results of this study indicate that budgeting activities, information asymmetry, organizational commitment, and environmental and environmental uncertainty in the City Device Agency (OPD) within the scope of the Denpasar City Government.
\end{abstract}

Keywords: Budgeting participation, information asymmetry, organizational commitment, environmental uncertainty, budgetary slack. 
Ida Bagus Surya Cahyadi Luhur dan Ni Luh Supadmi. Pengaruh...

\section{PENDAHULUAN}

Anggaran merupakan bagian penting dalam suatu organisasi baik sektor publik maupun perusahaan. Anggaran adalah rencana kegiatan organisasi yang dinyatakan dalam satuan moneter untuk menunjukkan kegiatan apa yang akan dilakukan oleh perusahaan. Anggaran memiliki fungsi-fungsi yang sama dengan manajemen yaitu fungsi perencanaan (planning), fungsi pelaksanaan (actuating), dan fungsi pengawasan (controlling). Anggaran sebagai alat manajemen dalam pelaksanaan fungsinya (Nafarin, 2009).

Anggaran adalah pernyataan mengenai estimasi kinerja yang hendak dicapai selama periode waktu tertentu yang dinyatakan dalam ukuran finansial, sedangkan penganggaran adalah proses atau metode untuk mempersiapkan suatu anggaran (Mardiasmo, 2009). Anggaran adalah salah satu komponen penting dalam perencanaan melihat ke masa depan, menentukan kegiatan apa yang akan dilakukan untuk mencapai tujuan, pengendalian dilakukan dengan tujuan supaya kegiatan yang telah direncanakan dapat dilaksanakan dengan baik sehingga dapat mencapai target atau tujuan yang ingin dicapai. Dengan menerjemahkan keseluruhan strategi ke dalam rencana dan tujuan organisasi, maka dibutuhkan sebuah anggaran.

Dalam organisasi sektor publik, penganggaran merupakan suatu proses politis dan merupakan bagian yang penting dan relevan. Sedangkan pada sektor swasta anggaran merupakan bagian dari rahasia perusahaan yang tertutup untuk publik, namun pada sektor publik anggaran justru harus diinformasikan kepada masyarakat untuk dikritik, didiskusikan dan diberi masukan. Anggaran sektor publik merupakan 
ISSN: 2302-8556

E-Jurnal Akuntansi Universitas Udayana

Vol.26.2.Februari (2019): 966-996

instrumen akuntabilitas atas pengelolaan dana publik dan pelaksanaan programprogram yang dibiayai dengan uang publik (Mardiasmo, 2009).

Bagi pemerintah daerah, anggaran merupakan dokumen/kontrak politik antara pemerintah dan Dewan Perwakilan Rakyat Daerah (DPRD) untuk masa yang akan datang (Mardiasmo, 2009), selanjutnya DPRD akan mengawasi kinerja pemerintah melalui anggaran. Adanya hubungan agen dan principal tersebut diharapkan dapat memudahkan proses pengawasan anggaran agar tidak terjadi perilaku yang disfungsional, karena anggaran dalam pemerintahan merupakan wujud pembangunan untuk mencapai kesejahteraan masyarakat. Penerapan teori keagenan dapat menimbulkan dampak positif berupa efisiensi, tetapi penerapannya sering menimbulkan perilaku disfungsional berupa senjangan anggaran.

Proses penyusunan anggaran melibatkan banyak pihak, mulai dari manajemen tingkat atas (top level management) sampai manajemen tingkat bawah (lower level management). Senjangan anggaran merupakan merupakan tindakan bawahan yang mengecilkan kapasitas produktifnya ketika bawahan diberi kesempatan untuk menentukan standar kinerjanya. Situasi ini menyebabkan perbedaan antara anggaran yang direalisasikan dengan anggaran yang sesuai dengan estimasi terbaik bagi organisasi. Terlebih lagi jika prestasi kerja seorang pemimpin dinilai dari prestasinya dalam mencapai anggaran yang telah ditetapkan. Dalam kondisi seperti ini pihak manajemen cenderung lebih banyak melakukan senjangan anggaran. Alasan yang mendasari seorang manajer melakukan senjangan anggaran diantaranya adalah untuk membangun kepercayaan orang- orang bahwa ketika anggaran dapat tercapai, maka 
Ida Bagus Surya Cahyadi Luhur dan Ni Luh Supadmi. Pengaruh...

mereka akan terlihat memiliki kinerja yang bagus di mata atasan. Senjangan anggaran juga sering kali digunakan untuk mengatasi kondisi ketidakpastian manakala tidak ada kejadian yang tak terduga, maka asumsinya manajer tersebut dapat mencapai atau melampaui anggarannya.

Senjangan anggaran dapat terjadi karena perhatian yang tidak memadai terhadap pembuat keputusan, komunikasi, proses persetujuan anggaran dan kepemimpinan yang tidak selektif (Apriyandi, 2011). Implikasinya, semakin tinggi kecenderungan organisasi pemerintah untuk melakukan senjangan anggaran semakin tinggi pula kecenderungan terjadinya inefisiensi anggaran, dengan demikian apabila anggaran tersebut disetujui sama artinya dengan melegalkan pemborosan uang rakyat (Rahmiati, 2013).

Setiap tahun pemerintah daerah menghimpun dan membelanjakan dana melalui Anggaran Pendapatan dan Belanja Daerah (APBD). Penyusunan anggaran merupakan rangkaian kegiatan yang melibatkan banyak pihak, diantara lain Dewan Perwakilan Rakyat (DPR), Dewan Perwakilan Rakyat Daerah (DPRD) diprovinsi/kabupaten/kota, dan Organisasi Perangkat Daerah.Organisasi Perangkat Daerah menginginkan setiap satuan kerja perangkat daerahnya memiliki kinerja yang benar dan bertanggung jawab dalam menjalankan tugas dan fungsinya, baik dalam hal perencanaan, pengorganisasian, pelaksanaan program, pengawasan dan evaluasi, termasuk di dalamnya adalah pertanggungjawaban anggaran. Keterlibatan mereka sangatlah dibutuhkan untuk meningkatkan komitmen dalam target anggaran. Pencapaian target anggaran tentunya merupakan salah satu tujuan yang ingin dicapai 
ISSN: 2302-8556

E-Jurnal Akuntansi Universitas Udayana

Vol.26.2.Februari (2019): 966-996

oleh mereka. Demi jenjang karir yang lebih tinggi di masa mendatang, penilaian kinerja hal tersebut memotivasi agen untuk melakukan senjangan anggaran. Dalam tahap persiapan dan perencanaan anggaran daerah juga sering terjadinya senjangan anggaran, karena didominasi oleh kepentingan eksekutif dan legislatif, serta anggaran kurang mencerminkan kebutuhan masyarakat. Senjangan anggaran akan menyebabkan bias dalam evaluasi kinerja agen pada unit pertanggungjawabannya dan berdampak pada kesalahan alokasi sumber daya.

Penyusunan anggaran di Kota Denpasar melibatkan banyak partisipasi baik dari unsur pemerintah, legislatif maupun masyarakat. Penyusunan anggaran terdiri dari beberapa tahapan mulai dari penetapan skala prioritas program dan kegiatan, Musyawarah Rencana Pembangunan (Musrenbang), tahap penyusunan anggaran dari masing-masing dinas/instansi, penelitian oleh tim anggaran pemerintah daerah (TAPD), pembahasan oleh legislatif dan diakhiri penetapannya oleh legislatif bersama pemerintah daerah.

Reformasi pemerintahan daerah berarti juga adanya reformasi keuangan daerah. Reformasi keuangan daerah dalam pelaksanaannya akan berdampak juga terhadap reformasi anggaran (budgeting reform) yang meliputi proses penyusunan, pengesahan, pelaksanaan dan pertanggungjawaban anggaran. Pertanggungjawaban Anggaran Pendapatan dan Belanja Daerah provinsi memerlukan pengesahan Menteri Dalam Negeri dan APBD kabupaten/kota dengan pengesahan Gubernur, maka saat ini pertanggungjawaban APBD hanya memerlukan pengesahan dari Dewan Perwakilan Rakyat Daerah melalui Peraturan Daerah (Perda) (Mardiasmo, 2009). 
Ida Bagus Surya Cahyadi Luhur dan Ni Luh Supadmi. Pengaruh...

Penyusunan Anggaran Pendapatan dan Belanja Daerah, harus disusun sesuai dengan kebutuhan penyelenggaraan pemerintah daerah, disusun tepat waktu sesuai tahapan dan jadwal, dilakukan secara transparan, melibatkan partisipasi masyarakat, memperhatikan rasa keadilan dan kepatutan, serta dilarang bertentangan dengan kepentingan umum, peraturan yang lebih tinggi, dan peraturan daerah lainnya.

Pencapaian target anggaran tentunya merupakan salah satu tujuan yang ingin dicapai, namun dalam praktiknya seringkali terjadi kekeliruan atau kesalahan dalam menentukan rancangan biaya maupun target pendapatan yang ingin dicapai. Senjangan anggaran akan berdampak pada kesalahan alokasi sumber daya dan bias dalam evaluasi kinerja agen pada unit pertanggungjawabannya (Suartana, 2010). Adapun Realiasai Anggaran Pendapatan dan Belanja Daerah kota Denpasar tahun 2012-2016 disajikan pada Tabel 1 berikut ini.

Tabel 1.

\begin{tabular}{ccccccc}
\multicolumn{6}{c}{ Realisasi Anggaran Pendapatan dan Belanja Daerah (APBD) Kota Denpasar } \\
Tahun Anggaran 2012 - 2016 (dalam jutaan rupiah) \\
\cline { 2 - 7 } Tahun \\
\cline { 2 - 7 } & Pendapatan & \multicolumn{3}{c}{ Belanja } \\
\hline 2012 & 1.249 .898 & 1.379 .049 & 110,33 & 1.437 .826 & 1.309 .529 & 91,08 \\
2013 & 1.493 .567 & 1.547 .605 & 103,62 & 1.706 .190 & 1.537 .883 & 90,04 \\
2014 & 1.687 .453 & 1.727 .968 & 102,40 & 1.884 .774 & 1.648 .378 & 87,46 \\
2015 & 1.820 .251 & 1.786 .400 & 98,14 & 1.842 .557 & 1.582 .159 & 85,88 \\
2016 & 1.882 .852 & 1.943 .152 & 103,20 & 1.858 .674 & 1.684 .628 & 90,64 \\
\hline
\end{tabular}

Sumber : BPKAD Kota Denpasar, 2018.

Berdasarkan Tabel 1 menunjukkan setiap tahun adanya perbedaan antara realisasi dengan target anggaran. Hal ini mencerminkan adanya senjangan anggaran, karena realisasi anggaran pendapatan daerah selalu lebih tinggi dari pada anggaran 
ISSN: 2302-8556

E-Jurnal Akuntansi Universitas Udayana

Vol.26.2.Februari (2019): 966-996

pendapatan daerah yang dianggarkan. Sedangkan, realisasi anggaran belanja daerah selalu lebih rendah daripada anggaran belanja daerah yang dianggarkan. Kondisi ini diduga disebabkan oleh beberapa faktor antara lain partisipasi penganggaran, informasi asimetri, komitmen organisasi, dan ketidakpastian lingkungan.

Partisipasi penganggaran sangat berpengaruh terhadap senjangan anggaran. Semakin tinggi partisipasi yang diberikan kepada bawahan dalam penganggaran akan cenderung mendorong bawahan menciptakan senjangan anggaran. Anggaran memiliki dampak langsung terhadap perilaku manusia. Orang- orang merasakan tekanan dari anggaran yang ketat dan kegelisahan atas laporan kinerja yang buruk sehingga anggaran sering kali dipandang sebagai penghalang kemajuan karir mereka.

Partisipasi anggaran merupakan salah satu faktor yang dianggap memiliki pengaruh signifikan pada senjangan anggaran. Penelitian yang dilakukan oleh Alfebriano (2013), Maiga (2008), Anggraeni (2008), dan Umar (2014) menyatakan bahwa partisipasi manajer tingkat bawah dalam pembuatan anggaran berpengaruh positif pada senjangan anggaran. Berbeda dengan hasil penelitian yang dilakukan oleh Ardanari dan Putra (2014), Apriyandi (2011), dan Dunk (1993) yang mengatakan bahwa partisipasi anggaran berpengaruh negatif pada senjangan anggaran.

Informasi asimetri merupakan perbedaan informasi yang dimiliki manajer tingkat atas dengan manajer tingkat bawah karena adanya perbedaan sumber dan akses atas informasi tersebut. Menurut Umar (2014:2), Informasi asimetri adalah kondisi dimana bawahan memiliki informasi yang lebih banyak dibandingkan dengan 
Ida Bagus Surya Cahyadi Luhur dan Ni Luh Supadmi. Pengaruh...

atasan, maupun sebaliknya. Bila kemungkinan yang pertama terjadi, akan muncul tuntutan yang lebih besar dari atasan kepada bawahan mengenai pencapaian target anggaran yang menurut bawahan terlalu tinggi. Namun bila kemungkinan yang kedua terjadi, bawahan akan menyatakan target lebih rendah dari pada yang dimungkinkan untuk dicapai.

Keadaan adanya salah satu pihak mempunyai pengetahuan lebih daripada yang lainnya terhadap sesuatu hal disebut informasi asimetri. Kondisi ini menyebabkan diterapkan sistem anggaran partisipatif agar informasi yang dimiliki bawahan dapat dikomunikasikan dengan atasan. Perbedaan informasi ini menjadi faktor utama terjadinya senjangan anggaran. Dewi dan Gerianta (2013) dan Ardanari dan Putra (2014) mengatakan bahwa informasi asimetri berpengaruh positif terhadap senjangan anggaran. Dwi dan Lidya (2010), Apriyandi (2011), dan Falikhatun (2007) mengatakan informasi asimetri berpengaruh signifikan negatif terhadap senjangan anggaran. Sedangkan hasil penelitian Bangun dan Kurniati (2012), Putranto (2012), dan Anggraeni (2008) menunjukkan bahwa informasi asimetri tidak mempengaruhi timbulnya senjangan anggaran.

Komitmen organisasi menunjukan keyakinan dan dukungan yang kuat terhadap nilai dan sasaran (goal) yang ingin dicapai organisasional (Mowday et al., 1979 dalam Pangastuti, 2008). Komitmen organisasi merupakan elemen penting dalam bekerja di organisasi pemerintahan. Seseorang dengan memiliki komitmen organisasi di organisasi pemerintah dapat diharapkan memiliki pandangan yang positif serta berusaha berbuat yang terbaik untuk mencapai tujuan dan kinerja yang 
ISSN: 2302-8556

E-Jurnal Akuntansi Universitas Udayana

Vol.26.2.Februari (2019): 966-996

lebih baik lagi. Hasil penelitian oleh Alfebriano (2013) menunjukkan bahwa komitmen organisasi tidak berpengaruh signifikan terhadap senjangan anggaran, sedangkan Dewi dan Gerianta (2013) mengatakan komitmen organisasi berpengaruh signifikan terhadap senjangan anggaran.

Variabel lain yang mempengaruhi senjangan anggaran adalah Ketidakpastian lingkungan menurut Menurut Kren dan Kerr (1993) dalam Sujana (2009), bagi suatu organisasi, sumber utama ketidakpastian berasal dari lingkungan yang meliputi pesaing, konsumen, pemasok, regulator, dan teknologi yang dibutuhkan. Hasil penelitian Govindarajan (1986) menyatakan bahwa hubungan antara partisipasi anggaran dan senjangan anggaran adalah positif dalam kondisi ketidakpastian lingkungan yang tinggi. Di dalam lingkungan relatif stabil (ketidakpastian rendah), individu dapat memprediksi keadaan di masa yang akan datang sehingga langkahlangkah yang akan dilakukannya dapat membantu organisasi menyusun rencana dengan lebih akurat.

Adanya ketidakkonsistenan dari hasil penelitian terdahulu mengenai faktorfaktor yang mempengaruhi senjangan anggaran menjadi alasan peneliti untuk melakukan penelitian kembali. Penelitian ini dilakukan pada Organisasi Perangkat DaerahKota Denpasar karena Kota Denpasar merupakan salah satu kota yang memiliki pendapatan asli daerah tertinggi ke tiga di provinsi Bali, sehingga diperkirakan Organisasi Perangkat Daerah Kota Denpasar memiliki tingkat partisipasi yang besar dalam proses penyusunan anggaran guna pembaruan pembangunan di Kota Denpasar. 
Ida Bagus Surya Cahyadi Luhur dan Ni Luh Supadmi. Pengaruh...

Berdasarkan uraian latar belakang di atas, maka rumusan masalah dalam penelitian ini adalah: 1) Apakah partisipasi penganggaran berpengaruh pada senjangan anggaran?; 2) Apakah informasi asimetri berpengaruh pada senjangan anggaran?; 3) Apakah komitmen organisasi berpengaruh pada senjangan anggaran?; 4) Apakah ketidakpastian lingkungan berpengaruh pada senjangan anggaran?. Tujuan dalam penelitian ini adalah untuk mengetahui pengaruh partisipasi anggaran, asimetri informasi, komitmen organisasi dan ketidakpastian lingkungan pada kesenjangan anggaran.

Dari tujuan penelitian tersebut, peneliti berharap berdasarkanhasil penelitian ini dapat memberikanmanfaat secara teoritis maupun praktis. Kegunaan teoritis dalam penelitian ini diharapkanmemberikan sumbangan konseptual ilmu pengetahuan bagi peneliti sejenis maupun peneliti lainnya dalam rangka mengembangkan ilmu pengetahuan untuk perkembangan dan kemajuan dunia pendidikan. Sedangkan kegunaan praktis penelitian ini diharapkan dapatmemberikan masukan dan dapat digunakan sebagai bahan masukan dan bahan pertimbangan bagi pimpinan Organisasi Perangkat Daerah terkait dalam penyusunan anggaran.

penelitian ini menggunakan Theory of Planned Behavio r(TPB) danTeori Kontijensi sebagai grand theory. Theory of Planned Behavior (TPB) merupakan teori yang menjelaskan bahwa perilaku yang ditimbulkan oleh individu muncul karena adanya niat untuk berperilaku. Teori ini menyatakan bahwa keputusan untuk menampilkan tingkah laku tertentu adalah proses rasional yang diarahkan pada suatu tujuan tertentu dan mengikuti urutan berpikir. faktor sentral dari perilaku individu 
adalah bahwa perilaku dipengaruhi oleh suatu niat (intention) individu terhadap sebuah perilaku tertentu (Ajzen, 1991).

Teori Kontijensi merupakan teori yang berlandaskan pada suatu pemikiran bahwa pengelolaan organisasi dapat berjalan dengan baik dan lancar apabila pemimpin organisasi mampu memperhatikan dan memecahkan situasi tertentu yang sedang dihadapi dan setiap situasi harus dianalisis sendiri.Teori kontinjensi dapat digunakan untuk menganalisis desain dan sistem akuntansi manajemen untuk memberikan informasi yang dapat digunakan perusahaan untuk berbagai macam tujuan dan untuk menghadapi persaingan (Otley, 1980).

Secara sistematis, kerangka konseptual dalam penelitian ini disajikan pada Gambar 1. berikut ini. 
Ida Bagus Surya Cahyadi Luhur dan Ni Luh Supadmi. Pengaruh...

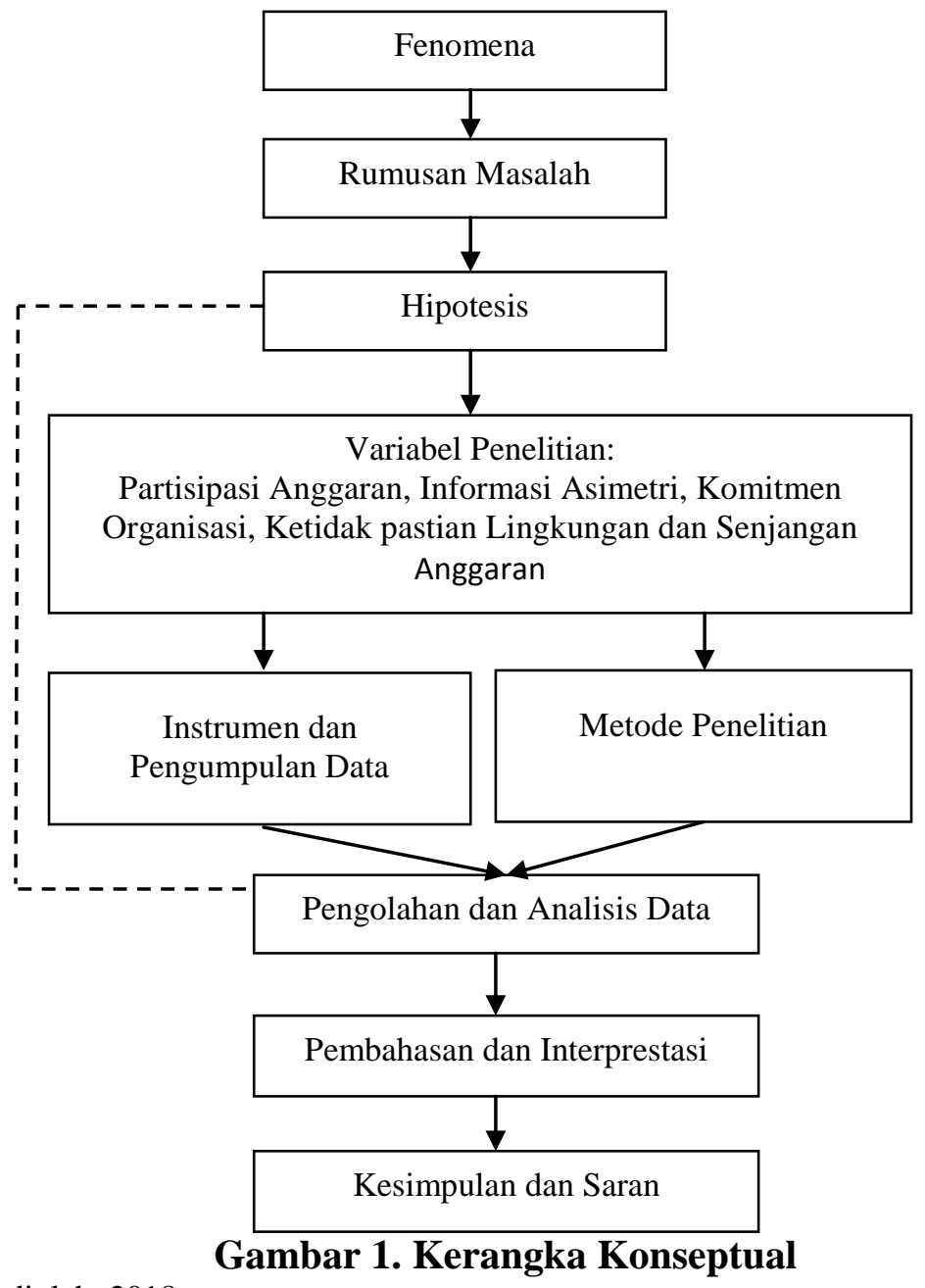

Sumber : Data diolah, 2018

\section{Gambar 1. Kerangka Konseptual}

Partisipasi yang tinggi dalam proses penyusunan anggaran akan memberikan kesempatan yang lebih besar kepada bawahan untuk melakukan senjangan dan sebaliknya ketika partisipasi rendah harapan bawahan untuk melakukan senjangan anggaran dibatasi sehingga senjangan anggaran juga rendah (Edfan, 2002). Berdasarkan teori planned behavior, keterlibatan manajer dalam menyusun anggaran dapat membuat perilaku manajer untuk melakukan senjangan anggaran karena ada kesempatan yang diberikan kepadanya.Penelitian Young (1985) dalam Edfan (2002), 
ISSN: 2302-8556

E-Jurnal Akuntansi Universitas Udayana

Vol.26.2.Februari (2019): 966-996

menyimpulkan bahwa terjadinya senjangan anggaran disebabkan karena bawahan tidak ingin menghadapi risiko. Manajer berharap dengan melakukan senjangan anggaran bertujuan agar sasaran dapat mudah dicapai dan menurunkan risiko kegagalan mencapai target anggaran.Penelitian Alfebriano (2013) selaras dengan penelitian yang dilakukan Widiananta (2005) yang meneliti pengaruh komitmen organisasi dan ketidakpastian lingkungan terhadap hubungan antara partisipasi anggaran dengan senjangan anggaran.

Untuk melakukan pengujian hubungan antara partisipasi anggaran dengan senjangan anggaran, maka peneliti menduga bahwa semakin rendah tingkat partisipasi anggaran, maka tingkat senjangan anggaran yang timbul akan semakin rendah, begitu pula sebaliknya partisipasi anggaran yang tinggi dari bawahan maka tingkat senjangan anggaran yang timbul akan semakin tinggi. Adanya partisipasi anggaran memberikan peluang bagi mereka untuk melonggarkan anggaran atau sengaja menciptakan senjangan, agar anggaran yang mereka susun mudah dicapai. Berdasarkan uraian diatas, maka dapat dirumuskan hipotesis sebagai berikut:

$\mathrm{H}_{1} \quad$ : Partisipasi penganggaran berpengaruh positif pada senjangan anggaran

Asimetri Informasi merupakan perbedaan informasi yang dimiliki oleh atasan dengan bawahan, dalam hal ini yaitu perbedaan informasi yang dimiliki oleh pimpinan Organisasi Perangkat Daerahdengan pegawai yang terlibat dalam penyusunan anggaran OPD. Berdasarkan teori keprilakuan, Informasi asimetri memberikan peluang pada penyusun anggaran untuk mempengaruhi anggaran yang mungkin tidak selalu sesuai dengan kepentingan maupun keinginan atasan. Biasanya 
Ida Bagus Surya Cahyadi Luhur dan Ni Luh Supadmi. Pengaruh...

penyusun anggaran akan menganggarkan sumber daya yang melebihi dari kebutuhan sebenarnya dengan maksud untuk memenuhi tujuan- tujuan mereka. Penelitian Alfebriano (2013) menggunakan lima variabel yaitu partisipasi penganggaran, informasi asimetri, penekanan anggaran, komitmen organisasi dan ketidakpastian lingkungan. Hasil penelitian Alfebriano (2013) menunjukkan bahwa informasi asimetri berpengaruh positif terhadap senjangan anggaran.

Penelitian Ardanari dan Putra (2014) menguji pengaruh partisipasi penganggaran, asimetri informasi, self estee dan budget emphasis pada budgetary slack menunjukkan bahwa informasi asimetri mempengaruhi timbulnya senjangan anggaran. Busuioc (2011) menyebutkan bahwa teori informasi asimetri mengacu pada ketidakpastian yang disebabkan karena agen memiliki informasi pribadi yang lebih banyak tentang bidangnya dibandingkan prinsipal, maka peneliti menduga bahwa semakin tinggi tingkat informasi asimetri maka tingkat senjangan anggaran yang timbul akan semakin tinggi, begitu pula sebaliknya ketika informasi asimetri rendah maka senjangan anggaran yang terjadi juga rendah. Sehingga akan ada kemungkinan mereka akan melonggarkan anggaran atau sengaja menciptakan senjangan, agar anggaran yang mereka susun mudah dicapai. Berdasarkan uraian diatas maka, dapat dirumuskan hipotesis sebagai berikut:

$\mathrm{H}_{2}$ : Asimetri informasi berpengaruh positif pada senjangan anggaran

Komitmen organisasi ialah sikap karyawan yang tertarik dengan tujuan, nilai dan sasaran organisasi yang ditunjukan dengan adanya penerimaan individu atas nilai dan tujuan organisasi serta memiliki keinginan untuk berafiliasi dengan organisasi 
ISSN: 2302-8556

E-Jurnal Akuntansi Universitas Udayana

Vol.26.2.Februari (2019): 966-996

dan kesediaan bekerja keras untuk organisasi sehingga membuat individu betah dan tetap ingin bertahan diorganisasi tersebut demi tercapainya tujuan dan kelangsungan organisasi. Berdasarkan teori kontijensi, pemikiran bahwa pengelolaan organisasi dapat berjalan dengan baik dan lancar apabila pemimpin organisasi mampu memperhatikan dan memecahkan situasi tertentu untuk mencapai tujuan tertentu dapat membuat komitmen organisasi semakin tinggi.

Komitmen akan membuat organisasi lebih produktif. Bagi individu dengan komitmen organisasi yang rendah akan memiliki perhatian yang rendah terhadap pencapaian tujuan organisasi dan akan cenderung berusaha memenuhi kepentingan pribadi. Bagi individu yang memiliki komitmen organisasi tinggi akan menganggap pencapaian tujuan organisasi merupakan hal yang penting. Hasil penelitian yang dilakukan oleh Dewi dan Gerianta (2013) mengatakan bahwa komitmen organisasi berpengaruh positif signifikan terhadap senjangan anggaran. Untuk menguji hubungan antara komitmen organisasi dengan senjangan anggaran, maka peneliti menduga bahwa semakin tinggi tingkat komitmen organisasi maka tingkat senjangan anggaran yang timbul akan semakin tinggi, begitu pula sebaliknya jika komitmen organisasi rendah maka tingkat senjangan anggaran yang timbul akan semakin rendah. Berdasarkan uraian diatas maka, dapat dirumuskan hipotesis sebagai berikut:

$\mathrm{H}_{3}$ : Komitmen organisasi berpengaruh positif pada senjangan anggaran Ketidakpastian lingkungan merupakan salah satu faktor yang sering menyebabkan organisasi melakukan penyesuaian terhadap kondisi organisasi dengan lingkungan. Sumber utama ketidakpastian berasal dari pesaing, konsumen, regulator, 
Ida Bagus Surya Cahyadi Luhur dan Ni Luh Supadmi. Pengaruh...

pemasok dan teknologi, yang dibutuhkan (Govindarajan, 1986). lingkungan yang tidak dapat diprediksi dan tidak dapat memahami komponen lingkungan yang akan berubah maka individu merasa mengalami ketidakpastian lingkungan yang tinggi (Milliken, 1978 dalam Darlis, 2002). individu dapat memprediksi keadaan di masa datang apabila langkah-langkah yang akan dilakukannya dapat direncanakan dengan lebih akurat (Duncan, 1972 dalam Darlis, 2002).

Berdasarkan teori kontijensi, pegawai cendereung akan meakukan senjangan anggaran untuk digunakan menganalisis desain dan sistem akuntansi manajemen untuk memberikan informasi yang dapat digunakan perusahaan untuk beragai macam tujuan dan menghadapi persaingan.Penelitian Tjahjanti (2004) menyatakan hasil bahwa meningkatnya senjangan anggaran disebabkan oleh ketidakpastian lingkungan yang tinggi dalam sebuah organisasi akan.Hasil analisis menunjukkan bahwa ketidakpastian lingkungan mempunyai pengaruh yang signifikan terhadap senjangan anggaran.

Pengujian mengenai hubungan antara ketidakpastian lingkungan dengan senjangan anggaran, maka peneliti mengacu pada hasil penelitian Tjahjanti (2004)dan Widiananta (2005) yang menduga bahwa ketidakpastian lingkungan yang tinggi dalam sebuah organisasi akan meningkatkan senjangan anggaran, begitu pula sebaliknya jika ketidakpastian lingkungan yang rendah dalam sebuah organisasi akan menurunkan senjangan anggaran.Berdasarkan uraian diatas maka, dapat dirumuskan hipotesis sebagai berikut:

$\mathrm{H}_{4}$ : Ketidakpastian lingkungan berpengaruh positif pada senjangan anggaran 
ISSN: 2302-8556

E-Jurnal Akuntansi Universitas Udayana

Vol.26.2.Februari (2019): 966-996

\section{METODE PENELITIAN}

Penelitian ini menggunakan pendekatan kuantitatif yang berbentuk asosiatif. Penelitian ini menjelaskan tentang pengaruh partisipasi anggaran, informasi asimetri, komitmen organisasi, dan ketidakpastian lingkungan pada senjangan anggaran. Penelitian ini dilakukan pada Instansi Pemerintah Kota Denpasar, yang dimana Kota Denpasar merupakan salah satu kota yang memiliki pendapatan asli daerah (PAD) tertinggi di provinsi Bali, sehingga diperkirakan Organisasi Perangkat Daerah Kota Denpasar memiliki tingkat partisipasi yang besar dalam proses penyusunan anggaran guna pembaruan pembangunan di Kota Denpasar.Objek penelitian dalam penelitian ini adalah variabel-variabel yang dapat memengaruhi kesenjangan anggaran, yaitu partisipasi anggaran, asimetri informasi, komitmen organisasi, dan ketidakpastian lingkungan.

Populasi dalam penelitian ini yaituOrganisasi Perangkat Daerah dalam lingkup Pemerintahan Kota Denpasar yang berjumlah sebanyak 33 OPD, yang terdiri dari Dinas, Badan, Kantor Kecamatan dan Inspektorat. Metode purposive sampling merupakan metode yang digunakan dalam pengambilan sampel penelitian ini.Metode ini digunakan bertujuan untuk menghindari adanya bias dari penelitian dengan memperoleh sampel yang sesuai dengan kriteria yang telahditentukan. pegawai yang mempunyai jabatan sebagai kepala dinas, kepala badan, kepala sub-bagian dan kepala sub-bidang yang ikut serta secara langsung dalam melakukan proses penyusunan anggaran pada setiap Organisasi Perangkat Daerah kota Denpasar. 
Ida Bagus Surya Cahyadi Luhur dan Ni Luh Supadmi. Pengaruh...

Metode pengumpulan data pada penelitian ini menggunakan metode survey dengan teknik pengumpulan data dengan menggunakan kuesioner (angket).Kuesioner yang disebarkan berupa daftar pernyataan kepada respondenmengenai partisipatif anggaran, informasi asimetri, komitmen organisasi, ketidakpastian lingkungan dan senjangan anggaran. Hasil jawaban tersebut kemudian diukur dengan menggunakan skala likert, yaitu pilihan jawaban responden diberi nilai dengan skala 4 poin. Teknik analisis data pada penelitian ini adalah Regresi Linier Bergandayang dihitung dengan program SPSS. Pengujian dapat dilakukanapabila model dari penelitian ini telah memenuhi syarat yaitu data harus, tidak mengandung multikolinearitas serta heteroskedastisitas dan berdistribusi normal (uji asumsi klasik). Pengujian selanjutnya yaitu, uji kelayakan model (Uji F)uji koefisien determinasi $\left(\mathrm{R}^{2}\right)$, setelah itu ujiregresi linier berganda, uji hipotesis (Uji t), dan statistik deskriptif. Model regresi penelitian ini dapat ditunjukkan dengan persamaan berikut.

$\hat{Y}=\alpha+\beta_{1} X_{1}+\beta_{2} X_{2}+\beta_{3} X_{3}+\beta_{4} X_{4}+e$

Keterangan :

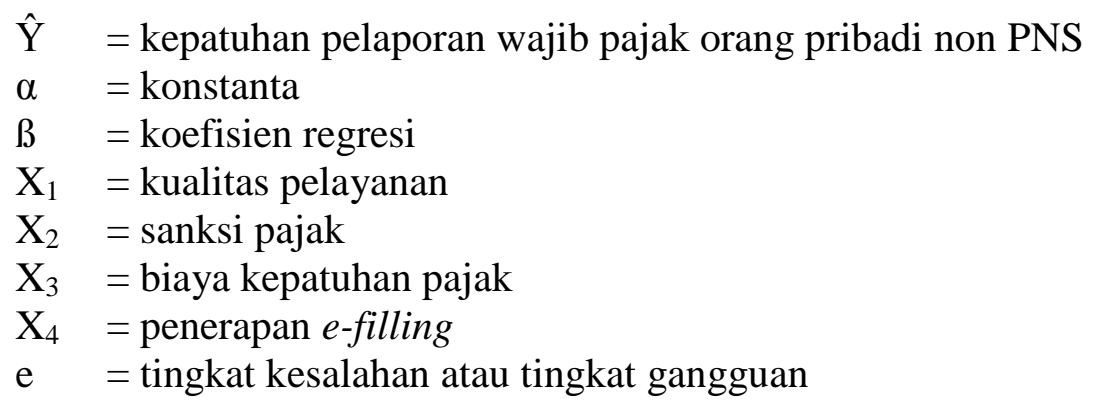


ISSN: 2302-8556

E-Jurnal Akuntansi Universitas Udayana

Vol.26.2.Februari (2019): 966-996

\section{HASIL DAN PEMBAHASAN}

Data penelitian diperoleh dari hasil kuesioner yang telah disebarkan kepada responden penelitian sejumlah 99 orang pegawai tetap yang bekerja di Organisasi Perangkat Daerah dalam lingkup Pemerintahan Kota Denpasar. Karakteristik responden meliputi jenis kelamin, umur, tingkat pendidikan dan lama kerja responden. Ringkasan mengenai karakteristik responden dapat dilihat pada Tabel 2 berikut ini.

Tabel 2.

Karakteristik Pegawai Organisasi Perangkat Daerah (OPD) dalam lingkup Pemerintahan Kota Denpasar

\begin{tabular}{|c|c|c|c|c|}
\hline No & Karakteristik & Klasifikasi & $\begin{array}{c}\text { Jumlah } \\
\text { Responden (orang) }\end{array}$ & $\begin{array}{l}\text { Persentase } \\
\text { Responden } \\
(\%)\end{array}$ \\
\hline \multirow{2}{*}{1} & \multirow{2}{*}{ Jenis Kelamin } & Laki-laki & 59 & 59,60 \\
\hline & & Perempuan & 40 & 40,40 \\
\hline \multirow{6}{*}{2} & \multirow[t]{2}{*}{ Jumlah } & & 99 & 100 \\
\hline & & 21 - 30 Tahun & 24 & 24,24 \\
\hline & \multirow{3}{*}{ Umur } & 31 - 40 Tahun & 39 & 39,39 \\
\hline & & $40-50$ Tahun & 26 & 26,26 \\
\hline & & > 50 Tahun & 10 & 10,10 \\
\hline & \multirow{2}{*}{ Jumlah } & & 99 & 100 \\
\hline \multirow{4}{*}{3} & & SMA & 27 & 27,27 \\
\hline & \multirow{3}{*}{$\begin{array}{c}\text { Jenjang Pendidikan } \\
\text { Terakhir }\end{array}$} & Diploma & 23 & 23,23 \\
\hline & & Sarjana & 41 & 41,41 \\
\hline & & Pascasarjana & 8 & 8,08 \\
\hline \multirow{5}{*}{4} & \multirow{2}{*}{ Jumlah } & & 99 & 100 \\
\hline & & $1-5$ tahun & 38 & 38,38 \\
\hline & \multirow[t]{2}{*}{ Lama Kerja } & 5-10 tahun & 51 & 51,52 \\
\hline & & $>10$ tahun & 10 & 10,10 \\
\hline & Jumlah & & 99 & 100 \\
\hline
\end{tabular}

Sumber :Data diolah,2018

Tabel 2 menunjukkan responden dalam penelitian ini didominasi berjenis kelamin laki-laki dengan jumlah sebanyak 59 orang atau sebesar 59,60 persen, Artinya lebih banyak pegawai laki-laki dibandingkan perempuan yang bekerja di Organisasi Perangkat Daerah dalam lingkup Pemerintahan Kota Denpasar. Dilihat 
Ida Bagus Surya Cahyadi Luhur dan Ni Luh Supadmi. Pengaruh...

dari segi usia, didominasi responden yang berusia 31-40 tahun sebanyak 39 orang atau sebesar 39,39 persen, Hal ini menunjukkan bahwa pegawai yang bekerja di Organisasi Perangkat Daerah dalam lingkup Pemerintahan Kota Denpasar mayoritas adalah yang berusia 31-40 tahun.

Tabel 2 juga menunjukkan mayoritas pegawai di Organisasi Perangkat Daerah dalam lingkup Pemerintahan Kota Denpasar adalah kelompok responden dengan tingkat pendidikan Sarjana dengan jumlah sebanyak 41 orang atau 41,41 persen, Informasi ini memberikan gambaran bahwa pegawai di Organisasi Perangkat Daerah dalam lingkup Pemerintahan Kota Denpasar paling dominan adalah lulusan Sarjana yang dianggap sudah mampu serta memadai untuk menjadi pegawai pemerintahan yang memiliki kompetensi untuk mencapai tujuan organisasi. Pengelompokkan responden berdasarkan masa kerjamenunjukkan bahwa mayoritas responden yangbekerja di Organisasi Perangkat Daerah dalam lingkup Pemerintahan Kota Denpasar dengan masa kerja yaitu selama 1 sampai 5 tahun adalah sebanyak 38 orang atau 38,38 persen.

Statistik deskriptif bertujuan untuk memberikan informasi mengenai karakteristik variabel - variabel penelitian yaitu jumlah amatan nilai minimum, nilai maksimum, nilai mean, dan standar deviasi (Sugiyono, 2014:206). Hasil statistik deskriptif penelitian ini dapat dilihat pada Tabel 3 berikut. 
ISSN: 2302-8556

E-Jurnal Akuntansi Universitas Udayana

Vol.26.2.Februari (2019): 966-996

Tabel 3.

Hasil Statistik Deskriptif Variabel Penelitian

\begin{tabular}{lrrrrr}
\hline & N & Minimum & Maximum & Mean & Std. Deviation \\
\hline Partisipasi Penganggaran & 99 & 12 & 24 & 18.43 & 2.195 \\
Informasi Asimetri & 99 & 11 & 24 & 18.56 & 3.045 \\
Komitmen Organisasi & 99 & 14 & 27 & 20.75 & 2.922 \\
Ketidakpastian Lingkungan & 99 & 13 & 28 & 21.52 & 3.284 \\
Senjangan Anggaran & 99 & 13 & 23 & 18.88 & 2.228 \\
Valid N (listwise) & 99 & & & &
\end{tabular}

Sumber :Data diolah, 2018

Tabel 3 menunjukkan variabel partisipasi penganggaran memiliki nilai minimum 12 dan nilai maksimum 24. Nilai rata-rata untuk variabel partisipasi anggaran sebesar 18,43 dengan nilai standar deviasi sebesar 2,195. Nilai standar deviasi lebih rendah dibandingkan dengan nilai rata-rata, hal ini berarti sebaran data terkait dengan partisipasi anggaran sudah merata.

Variabel informasi asimetri memiliki nilai minimum 11 dan nilai maksimum 24. Nilai rata-rata untuk variabel informasi asimetri sebesar 18,56 dengan nilaistandar deviasi sebesar 3,045. Nilai standar deviasi ini lebih rendah dibandingkan dengan nilai rata-rata, hal ini berarti sebaran data terkait informasi asimetri sudah merata.

Variabel komitmen organisasi memiliki nilai minimum 14 dan nilai maksimum 27. Nilai rata-rata untuk variabel komitmen organisasi sebesar 20,75 dengan nilai standar deviasi sebesar 2,922.Nilai standar deviasi ini lebih rendah dibandingkan dengan nilai rata-rata, hal ini berarti sebaran data terkait komitmen organisasi sudah merata.

Variabel ketidakpastian lingkungan memiliki nilai maksimum 13 dan nilai minimum yaitu 28. Nilai rata-rata untuk variabel ketidakpastian lingkungan sebesar21,52dengan nilai standar deviasi sebesar 3,284.Nilai standar deviasi ini lebih 
Ida Bagus Surya Cahyadi Luhur dan Ni Luh Supadmi. Pengaruh...

rendah dibandingkan dengan nilai rata-rata, hal ini berarti sebaran data terkait ketidakpastian lingkungan sudah merata.

Variabel senjangan anggaran memiliki nilai minimum 13 dan nilai maksimum 23. Nilai rata-rata untuk variabel senjangan anggaran sebesar 18,88 dengan nilai standar deviasi sebesar 22,28. Nilai standar deviasi ini lebih rendah dibandingkan dengan nilai rata-rata, hal ini berarti sebaran data terkait senjangan anggaran sudah merata.

Tujuan dilakukannya uji normalitas yaitu untuk menguji apakah dalam residual dari model regresi yang dibuat telah berdistribusi normal. Uji KomogorovSminarnov dilakukan untuk menguji uji normalitas. Nilai Asymp. Sig. (2-tailed) yang disajikan pada Tabel 4 yaitu sebesar 0,918 , yang dimana lebih besar dari 0,05 makadapat disimpulkan bahwa seluruh databerdistribusi normal.

Tabel 4. Hasil Uji Normalitas

\begin{tabular}{cc}
\hline & Unstandardized Residual \\
\hline $\mathrm{N}$ & 99 \\
Kolmogorov-Smirnov Z & 0,554 \\
Asymp.Sig.(2-tailed) & 0,918 \\
\hline Sumber: Data diolah, 2018
\end{tabular}
Sumber: Data diolah, 2018

Tujuan dilakukannya uji multikolinieritas yaitu untuk menguji apakah dalam model regresi ditemukan adanya korelasi antara variabel independen. Nilai cut off yang dipakai untuk menunjukkan adanya multikolinearitas adalah nilai VIF $\geq 10$ atau nilai tolerance $\leq 0,10$. Hasil uji multikolinieritas disajikan pada Tabel 5 berikut. 
ISSN: 2302-8556

E-Jurnal Akuntansi Universitas Udayana

Vol.26.2.Februari (2019): 966-996

Tabel 5.

Hasil Uji Multikoleniaritas

\begin{tabular}{lccc}
\hline \multicolumn{1}{c}{ Variabel } & Tolerance & VIF & Keterangan \\
\hline Partisipasi penganggaran $\left(\mathrm{X}_{1}\right)$ & 0,647 & 1,546 & Bebas multikol \\
Informasi asimetri $\left(\mathrm{X}_{2}\right)$ & 0,500 & 2,001 & Bebas multikol \\
Komitmen organisasi $\left(\mathrm{X}_{3}\right)$ & 0,676 & 1,478 & Bebas multikol \\
Ketidakpastian Lingkungan $\left(\mathrm{X}_{4}\right)$ & 0,525 & 1,906 & Bebas multikol \\
\hline
\end{tabular}

Sumber: Data diolah,2018.

Berdasarkan hasil perhitungan tabel diatas, nilai nilai tolerance lebih besar dari 0,1dan nilai VIF lebih kecil dari 10, Sehingga disimpulkan bahwa antar variabel independen tidak terjadi atau bebas multikolinearitas.

Tujuan dilakukannyauji heteroskedatisitas yaitu untuk menguji apakah dalam model regresi terjadi ketidaksamaan variance dari residual untuk semua pengamatan. Uji Glejserdigunakan untuk menguji uji heterokedastisitas di dalam penelitian ini. Apabila tingkat signifikansi lebih besar dari $\alpha=0,05$ maka model regresi yang dianalisis tidak adanya gejala heteroskedastisitas.Hasil uji heteroskedastisitas disajikan pada Tabel 6 berikut.

Tabel 6.

Hasil Uji Heteroskedastisitas

\begin{tabular}{clcl}
\hline No & \multicolumn{1}{c}{ Variabel Bebas } & Signifikansi & Keterangan \\
\hline 1 & Partisipasi pengangaran $\left(\mathrm{X}_{1}\right)$ & 0,998 & Bebas heteros \\
2 & Informasi asimetri $\left(\mathrm{X}_{2}\right)$ & 0,265 & Bebas heteros \\
3 & Komitmen organisasi $\left(\mathrm{X}_{3}\right)$ & 0,404 & Bebas heteros \\
4 & Ketidakpastian lingkungan $\left(\mathrm{X}_{4}\right)$ & 0,151 & Bebas heteros \\
\hline
\end{tabular}

Sumber: Data diolah, 2018

Dari hasil pengujian pada Tabel 6, tingkat signifikansi seluruh variabel berada diatas 0,05 hal ini menunjukkan model regresi dalam penelitian ini bebas dari heteroskedastisitas. 
Ida Bagus Surya Cahyadi Luhur dan Ni Luh Supadmi. Pengaruh...

Uji Regresi Linier Berganda yang digunakan dalam penelitian ini untuk menguji pengaruh variabel partisipasi anggaran, informasi asimetri, komitmen organisasi, ketidakpastian lingkungan pada senjangan anggaran. Hasil uji analisis regresi linier berganda dapat disajikan pada Tabel 7 berikut.

\section{Tabel 7.}

\section{Hasil Uji Analisis Regresi Linier Berganda}

\begin{tabular}{|c|c|c|c|c|c|}
\hline \multirow[t]{2}{*}{ Model } & \multicolumn{2}{|c|}{$\begin{array}{c}\text { Unstandardized } \\
\text { Coefficients }\end{array}$} & \multirow{2}{*}{$\begin{array}{r}\begin{array}{r}\text { Standardized } \\
\text { Coefficients }\end{array} \\
\text { Beta }\end{array}$} & \multirow[t]{2}{*}{$\mathbf{t}$} & \multirow[t]{2}{*}{ Sig. } \\
\hline & B & Std. Error & & & \\
\hline (Constant) & 2,105 & 1,241 & & 1,696 & 0,093 \\
\hline Partisipasi Anggaran & 0,410 & 0,074 & 0,404 & 5.523 & 0,000 \\
\hline Informasi Asimetri & 0,207 & 0,061 & 0,283 & 3.401 & 0,001 \\
\hline Komitmen Organisasi & 0,128 & 0,055 & 0,167 & 2.338 & 0,021 \\
\hline Ketidakpastian Lingkungan & 0,127 & 0,055 & 0,187 & 2.300 & 0,024 \\
\hline Adjusted $R$ Square & & & 0,661 & & \\
\hline F hitung & & & 48,746 & & \\
\hline Signifikansi F & & & 0,000 & & \\
\hline
\end{tabular}

Sumber : Data diolah, 2018

Berdasarkan Tabel 7, dapat disusun persamaan regresi adalah sebagai berikut.

$$
Y=2,105+0,410 X_{1}+0,207 X_{2}+0,128 X_{3}+0,127 X_{4}+e
$$

Pada Tabel 7 diatas, dapat dilihat bahwa nilai dari uji $\mathrm{F}$ dalam penelitian ini yaitu 0,000 dengan signifikansi uji $\mathrm{F} 0,000<0,05$ yang berarti model regresi layak digunakan.

Nilai Adjusted R Square model (Uji koefisien determinasi) pada Tabel 7 sebesar 0,661 artinya 66,1 persen senjangan anggaran dipengaruhi oleh partisipasi penganggaran, informasi asimetri, komitmen organisasi, dan ketidakpastian lingkungan, sedangkan 33,9 persen dijelaskan oleh variabel lain diluar model. 
ISSN: 2302-8556

E-Jurnal Akuntansi Universitas Udayana

Vol.26.2.Februari (2019): 966-996

Hasil pengujian variabel partisipasi penganggaran pada Tabel 7 menunjukkan variabel partisipasi penganggaran mempunyai koefisien regresi sebesar 0,410 dengan signifikansi sebesar 0,000 yang dimana lebih kecil dari tingkat signifikansi 0,05menunjukkan bahwa partisipasi penganggaran berpengaruh positif dan signifikan pada senjangan anggaran, sehingga $\mathrm{H}_{1}$ diterima. Hal ini berarti bahwa semakin tinggi tingkat partisipasi penganggaran maka tingkat senjangan anggaran yang timbul akan semakin tinggi. Adanya partisipasi penganggaran memberikan peluang bagi mereka untuk melonggarkan anggaran atau sengaja menciptakan senjangan, agar anggaran yang mereka susun mudah dicapai. Hasil penelitian ini mendukung beberapa hasil penelitian sebelumnya dan konsisten dengan hasil penelitian yang dilakukan oleh Alfebriano (2013), Widiananta (2005), Kartika (2010), dan Mulyani (2012) yang memperoleh hasil bahwa partisipasi penganggaran berpengaruh positif dan signifikan terhadap senjangan anggaran.

Hasil pengujian variabel informasi asimetri pada Tabel 7, menunjukkan variabel informasi asimetri memiliki koefisien regresi sebesar 0,207 dengan signifikansi sebesar 0,001 yang dimana lebih kecil dari tingkat signifikansi 0,05 menunjukkan bahwa informasi asimetri berpengaruh positif pada senjangan anggaran, sehingga $\mathrm{H}_{2}$ diterima. Hal ini berarti bahwa semakin tinggi tingkat informasi asimetri maka tingkat senjangan anggaran yang timbul akan semakin tinggi, begitu pula sebaliknya ketika informasi asimetri rendah maka senjangan anggaran yang terjadi juga rendah. Sehingga akan ada kemungkinan mereka akan melonggarkan anggaran atau sengaja menciptakan senjangan, agar anggaran yang mereka susun mudah 
Ida Bagus Surya Cahyadi Luhur dan Ni Luh Supadmi. Pengaruh...

dicapai. Hasil penelitian ini juga didukung oleh beberapa hasil penelitian sebelumnya dan konsisten dengan hasil penelitian Alfebriano (2013), Ardanari dan Putra (2014), serta Busuioc (2011) yang memperoleh hasil bahwa informasi asimetri berpengaruh positif dan signifikan.

Hasil pengujian variabel komitmen organisasi pajak pada Tabel 7 menunjukkan koefisien regresi sebesar 0,128 dengan signifikansi sebesar 0,021 yang dimana lebih kecil dari tingkat signifikansi 0,05 menunjukkan bahwa biaya kepatuhan pajak berpengaruh positif pada senjangan anggaran, maka semakin tinggi tingkat komitmen organisasi maka tingkat senjangan anggaran yang timbul akan semakin tinggi. Hal ini terjadi karena saat individu loyal terhadap organisasinya, maka akan muncul kesediaan untuk melakukan dan mengupayakan segala hal yang terbaik dalam pencapaian tujuan organisasi. Hasil penelitian ini didukung oleh beberapa hasil penelitian sebelumnya dan konsisten dengan hasil penelitian Dewi dan Gerianta (2013) mengatakan bahwa komitmen organisasi berpengaruh positif signifikan terhadap senjangan anggaran.

Hasil pengujian variabel ketidakpastian lingkunganpada Tabel 7menunjukkan koefisien regresi sebesar 0,127 dengan signifikansi sebesar 0,024 yang dimana lebih kecil dari tingkat signifikansi 0,05 menunjukkan ketidakpastian lingkungan berpengaruh positif padasenjangan anggaran. Hal ini berarti bahwa ketidakpastian lingkungan yang tinggi dalam sebuah organisasi akan meningkatkan senjangan anggaran, begitu pula sebaliknya jika ketidakpastian lingkungan yang rendah dalam sebuah organisasi akan menurunkan senjangan anggaran. Hasil penelitian ini 
ISSN: 2302-8556

E-Jurnal Akuntansi Universitas Udayana

Vol.26.2.Februari (2019): 966-996

didukung oleh beberapa hasil penelitian sebelumnya dan konsisten dengan hasil penelitian Tjahjanti (2004), Widiananta (2005) yang memperoleh hasil bahwa ketidakpastian lingkungan berpengaruh positif dan signifikan.

\section{SIMPULAN}

Berdasarkan hasil penelitian yang sudah diuraikan sebelumnya, simpulan yang dapat diperoleh adalah penelitian ini Partisipasi penganggaran, informasi asimetri, komitmen organisasi, dan ketidakpastian lingkungan berpengaruh positif pada senjangan anggaran di Organisasi Perangkat Daerah dalam lingkup Pemerintahan Kota Denpasar. Hal ini berarti bahwa semakin tinggi tingkat partisipasi penganggaran, informasi asimetri, komitmen organisasi, serta ketidakpastian lingkungan maka tingkat senjangan anggaran yang timbul akan semakin tinggi.

Saran yang dapat peneliti usulkan dari hasil penelitian dan simpulan yang sudah dipaparkan di atas adalah OPD pemerintah kota Denpasar dalam proses penganggaran harus memperhatikam faktor-faktor lain pendorong terjadinya senjangan anggaran dalam penelitian ini hanya terdiri dari partisipasi penganggaran, informasi asimetri, komitmen organisasi, dan ketidakpastian lingkungan Pemerintah Daerah Kota Denpasar juga sebaiknya mengoptimalkan Organisasi Perangkat Daerah dalam berbagai kegiatan dan khususnya dalam penyusunan anggaran, sehingga penyelenggaraan anggaran dapat dilakukan dengan efektif dan efisien. 
Ida Bagus Surya Cahyadi Luhur dan Ni Luh Supadmi. Pengaruh...

Hasil dari penelitian ini diharapkan mampu mendorong peneliti-peneliti selanjutnya untuk mengamati faktor-faktor lain yang dapat mempengaruhi senjangan anggaran dan dapat menambah jumlah sampel penelitian serta memperluas wilayah sampel peneliti, sehingga nanti hasilnya dapat digeneralisasikan untuk lingkup yang lebih luas.

\section{REFERENSI}

Achyarsyah, Padri. 2015. Organizational Commitment of Public Accounting Firm, Implementation of an Independent Audit of the Financial Statements and Audit Quality. Research Juornal of Finance and Accounting, 3(5), pp: 155-345.

Agung, I Gusti Ayu Surya Cinitya Ardanari, dan I Nyoman Wijana Asmara Putra. 2014. Pengaruh Partisipasi Penganggaran, Asimetri Informasi, Self Estee Dan Budget Emphasis Pada Budgetary Slack. E-Jurnal Akuntansi Universitas Udayana, 7(3), hal: 56-70.

Alfebriano. 2013. Faktor-Faktor yang Mempengaruhi Slack Anggaran pada PT. BRI di Kota Jambi. E-Jurnal Binar AkuntansiFakultas Ekonomi Universitas Jambi, 2(1), hal : 78-89.

Anggraeni, Rika Sari. 2008. Pengaruh Partisipasi Anggaran, Information Asymetry, dan Budget Emphasis terhadap Slack Anggaran (Studi Pada PT. Jasa Raharja (Persero) Cabang Daerah Istimewa Yogyakarta). Skripsi Universitas Islam Indonesia, Yogyakarta.

Apriyandi. 2011. Pengaruh Informasi Asimetri terhadap Hubungan Antara Anggaran Partisipatif dan Budgetary Slack pada pemerintahan Kabupaten Wejo Makasar. Simposium Nasional Akuntansi VI.

Ardanari, I Gusti dan I Nyoman W.A. Putra. 2014. Pengaruh Partisipasi Penganggaran, Asimetri Informasi, Self Esteem dan Budget Emphasis pada Budgetary Slack. E-Jurnal AkuntansiUniversitas Udayana, 7(2), hal: 56-78.

Bangun, Nurainun dan Kurniati W. Andani. 2012. Pengaruh Budgetary Partisipation, Information Asymmetry, Budget Emphasis, dan Self Esteem terhadap Budgetary Slack. Jurnal AkuntansiUniversitas Tarumanegara, 12(1), hal: 577-594. 
ISSN: 2302-8556

E-Jurnal Akuntansi Universitas Udayana

Vol.26.2.Februari (2019): 966-996

Brownell. 1982. A Field Study Examination Of Budgetary Participation And Locus Of Control. The Accounting Review, october.

Busuoic, Andrada dan Ristian Radu Birau. 2011. The Role of Information Asymmetryin The Outburst and The Deepening of The Contemporary Economic Crisis.Academy of Economic Studies Journal, 9(3), pp: 968-1010.

Darlis, Edfan. 2002. Analisis Pengaruh Komitmen Organisasi dan Ketidakpastian Lingkungan terhadap Hubungan Antara Partisipasi Anggaran dengan Senjangan Anggaran. Jurnal Riset akuntansi Indonesia, 5(1), hal: 85:101.

Dewi, Ni Luh Putu S. dan Gerianta W. Y. 2013. Analisis Pengaruh Anggaran Partisipatif pada Budgetary Slack dengan Empat Variabel Moderasi (Studi Kasus pada SKPD Kabupaten Badung, Bali). Jurnal Universitas Udayana, 9(1), hal: 78-89.

Duncan, R.B. 1972. Characteristics of Organizational Environments and Perceived Environmental Uncertainty, Administrative Science Quarterly.

Dunk, Alan S. 1993. The Effect of Budget Emphasis and Information Asymmetry on the Relation Between Budgetary Participation and Slack. The Accounting Review, 68(2), pp: 391-400.

Dwi, Christine dan Lidya Agustina. 2010. Pengaruh Participation Budgeting, Information Asimetry dan Job Relevant Information terhadap Budget Slack pada Institusi Pendidikan. Jurnal Akuntansi Universitas Kristen Maranatha, 2(2), 101-121.

Falikhatun. 2007. Interaksi Informasi Asimetri, Budaya Organisasi dan Group Cohensiveness Dalam Hubungan Antara Partisipasi Penganggaran dan Budgetary Slack (Studi Kasus pada Rumah Sakit Umum Daerah Se-Jawa Tengah). Simposium Nasional Akuntansi (SNA) X, Makasar.

Falikhatun. 2007. Pengaruh Partisipasi Penganggaran Terhadap Budgetary Slack dengan Variabel Pemoderasi Ketidakpastian lingkungan dan Kohesivitas Kelompok. Jurnal Akuntansi dan Keuangan, 6(2), pp: 2007-221.

Gerloff, E.A, Muir, N.K, dan Bodensteiner, W.D. 1991. Three Components of Perceived Environmental Uncertainly : An Exploratory Analysys of The Effects of Aggregation. Journal of management, 17, pp: 749-768.

Govindarajan, V. 1986. Impact of Participation in The Budgetary Process on Managerial Attitudes and Performance: Universalitic and Contingency 
Ida Bagus Surya Cahyadi Luhur dan Ni Luh Supadmi. Pengaruh...

Govindarajan, V. 1986. Impact of Participation in The Budgetary Process on Managerial Attitudes and Performance: Jurnal of Universalitic and Contingency, 17, pp: 800-810.

Gregson, T., Wendell, J., \& Aono, J. 1994. Role Ambiguity, Role Conflict And Perceived Environmental Uncertainty : Are The Scales Measuring Separate Construcs For Accountant? Behavioral Research In Accounting, 16(1), pp: 678:700.

Kartika, Andi. 2010. Pengaruh Komitmen Organisasi Dan Ketidakpastian Lingkungan Dalam Hubungan Antara Partisipasi Anggaran Dengan Senjangan Anggaran (Studi Empirik Pada Rumah Sakit Swasta di Kota Semarang). Jurnal Program Studi Akuntansi Universitas Stikubank, 2(1), hal: 39-60.

Kennis, Izzetin. 1979. Effect of Budgetaary Goal Characteristic on Manajerial Attitudes and performance. The Accounting review, January, pp: 123-130.

Licata, Michael P., Robert H. Strawser, dan Robert B. Welker. !996.A Note on Participation in Budgeting and Locus of Control. The Accounting Review. January, pp: 112-117.

Milliken, F.J, 1987. Three Types of Perceived Uncertainty about The Environment : State, Effect, and Response Uncertainty. Academy of Management Review, 12, pp: 13-14.

Mowday, R. T., Steers, R. M.,\&Porter, L.W. 1979. The measurement of organizational commitment. Journal of Vocational Behavior, 55(1), pp: 308315.

Mulyani, Sri. 2012. Pengaruh Partisipasi Penganggaran, Tekanan Anggaran, Komitmen Organisasi dan Kompleksitas Tugas terhadap Slack Anggaran pada Perbankan di Pekanbaru. Jurnal Akuntansi Fakultas Ekonomi Universitas Islam Riau, 14(11), hal: 67-70.

Outley, D., Broadbent, j. \& Berry, A. 1995. Research in Management Control: An Overview of its Development. British Journal of Management, 2(4), pp: 204215.

Putranto, Yohanes Andri. 2012. Pengaruh Moderasi Informasi Asimetri dan Group Cohesiveness terhadap Hubungan Partisipasi Penganggaran dengan Budgetary Slack. Jurnal EkonomiSekolah Tinggi Ilmu Ekonomi Musi Palembang, 8(2), hal.: 78-82. 
Schiff, M and A. W. Lewin. 1970. The Impact of People on Budgets. The Accounting Review, 164, pp: 320-340.

Sujana, I Ketut. 2009. Pengaruh Partisipasi Penganggaran, Penekanan Anggaran, Komitmen Organisasi, Asimetri Informasi, dan Ketidakpastian lingkungan terhadap Budgetary Slack Pada Hotel-Hotel Berbintang di Kota Denpasar. Jurnal Akuntansi Fakultas Ekonomi Universitas Udayana, 17(1), hal: 52-56.

Umar, Meriska. 2014. Pengaruh Partisipasi Anggaran dan Asimetri Informasi terhadap Timbulnya Budgetary Slack pada Pemerintah Kabupaten Bone Bolango. JurnalUniversitas Negeri Gorontalo, 1(1), hal: 34-41.

Young, S. M. 1985. Participative Budgeting : The Effect of Risk Aversion and Asymmetric Information on Budgetary Slack. Journal of Accounting Research, pp: 829-842. 